Artigo Original

\title{
Monitoring of the erosion process of the gully type in the Cesamar Park in the Municipality of Palmas - TO
}

\author{
Monitoramento do processo erosivo do tipo Voçoroca no Parque Cesamar no \\ Município de Palmas - TO
}

\section{Ana Karla C. Aragão de Faria', Joel Carlos Zukowski Junior", Flavio Augustus da Mota Pacheco"II}

\section{Abstract}

This article aims to monitor the evolution of the erosive process of the gully type, observed in slopes and bed of water course affluent to Córrego Brejo Comprido, caused by the discharges of urban drainage network from part of the avenues LO 07 and LO 05, in the green area 304 (AVSE 33). The methodology used was to conduct on-site surveys with descriptive analysis, collection of points using GPS and the elaboration of monitoring reports. The results obtained after the monitoring identified the serious environmental problem, which is in an evolutionary and accentuated process, was also satisfactory to propose the measures of stabilization of the erosive process in the degraded area.

Keywords: Gully; Monitoring; Stabilization

\section{Resumo}

Este artigo visa monitorar a evolução do processo erosivo do tipo voçoroca, observado em taludes e leito de curso d'água afluente ao Córrego Brejo Comprido, provocado pelas descargas de rede de drenagem urbana advinda de parte das avenidas LO 07 e LO 05, na área verde 304 (AVSE 33). A metodologia utilizada foi a realização de vistorias in loco com análise descritiva, coleta de pontos com a utilização de GPS e elaboração de relatórios de monitoramento. Os resultados obtidos após o monitoramento identificaram o grave problema ambiental, que se encontra em processo evolutivo e acentuado, também foi satisfatório para propor as medidas de estabilização do processo erosivo na área degradada.

Palavras-chave: Voçoroca; Monitoramento; Estabilização 


\section{Introduction}

The erosive process of the gully type is characterized by being a result of the subsurface flow through movements transverse to the water flows, caused by the weathering action, which stimulates the soil to erosion (NORONHA, 2015).

The erosion of the slope is of worries to the competent authorities, since the existing natural processes, added to those caused by the execution of the works, can be improved by exposing their surfaces to the natural processes of mechanical, physical and biological alteration (MOREIRA and POLIVANOV, 2018) .

Soil erosion processes are a problem at the global level, generally due to the inadequate use of the land for agropastoral purposes. According to the Food and Agriculture Organization of the United Nations (FAO, 2015) study, $33 \%$ of the land in use in the world is degraded. Many resources are invested in these areas in order to control the processes, but the lack of knowledge of the cause and the phenomenon, even with investments, causes erosions to intensify and cause greater losses (ZANATTA et al, 2017).

For urban areas, the consequences the erosion process of the gully type is sedimentation of the riverbeds, canals and galleries of rainwater, whereas when the river gutters, channels, culverts and pipes fill, the draining rainwater compromised, thus facilitating the flooding process. Thus, the costs for recovery of these areas are high, necessitating preventive and / or analytical studies of the causative agents or evolution of the gullies, in order to identify the successive stages of erosion in the area (DA SILVA SANTANA and ARAUJO, 2018).

Pascoto et al. (2018) concluded in their study carried out in the city of São Manuel of the state of São Paulo that the anthropic action triggered most of the erosive processes analyzed, caused by the asphalting of streets without the previous analysis and study of the orientation of the rainwater, resulting in works of surface drainage. Furthermore, erosion processes, even in less advanced stages, because they are not stabilized, could evolve to greater dimensions and serious urban consequences and economic losses.

Carvalho et al. (2017) complement, after the analysis of gullies in an area between the city of Manaus and Presidente Figueiredo in Amazonas, that the main characteristic of the erosive processes is the fact that its development occurs in a slow but continuous and progressive way. To revert the process requires great economic and technical demands, and it is advisable, therefore, to invest prevention efforts, such as the implantation and captation of effective rainwater management.

The Municipal Environmental Foundation of Palmas TO (FMA) carried out surveys and descriptive analyzes with the elaboration of reports of environmental monitoring, in order to propose measures that attenuate the erosive process (gully) observed in slopes and bed of course d ' water flow to the Brejo Comprido stream, caused by discharges from the urban drainage network from part of the avenues LO 07 and LO 05, in the green area 304 (AVSE 33), in the municipality of Palmas-TO.

The objective of this work is to describe the erosion process characterized as gully located in the Cesamar Park in the municipality of Palmas - TO, as well as propose stabilization measures of the process, since it is in a state of evolution.

\section{Materials and methods}

In order to evaluate the situation of the erosion process in the Cesamar Park, the Environmental Monitoring Management team of the Palmas Municipal Environmental Foundation, composed of a geologist and two biologists, analyzed and monitored the evolution of the process, with surveys and use to define and physically characterize the erosive process. To that end, the reports and works already carried out on the problems of the area

Figure 1 - Location of the erosive process of the AVSE block 33

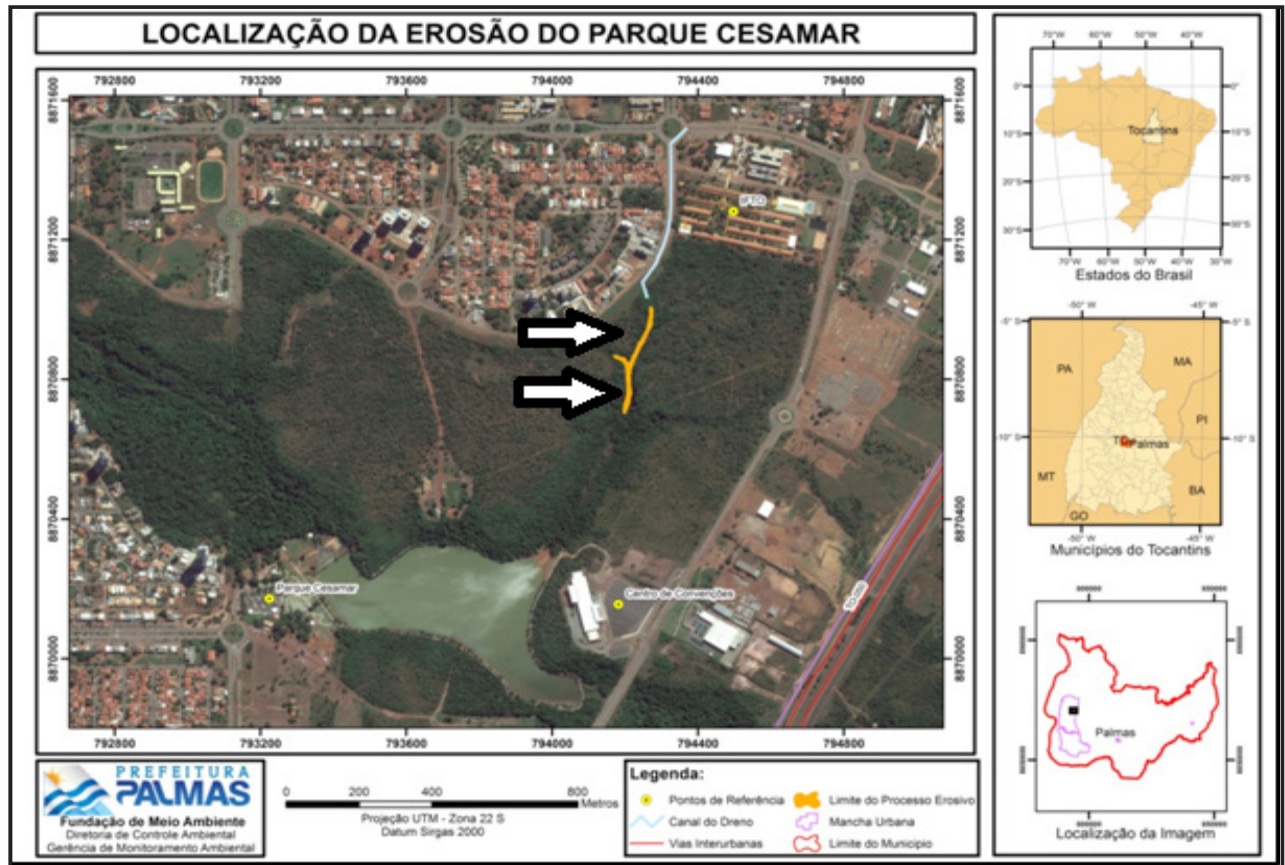

Source: FMA (2015) 
Figure 2 - Supression of native vegetation

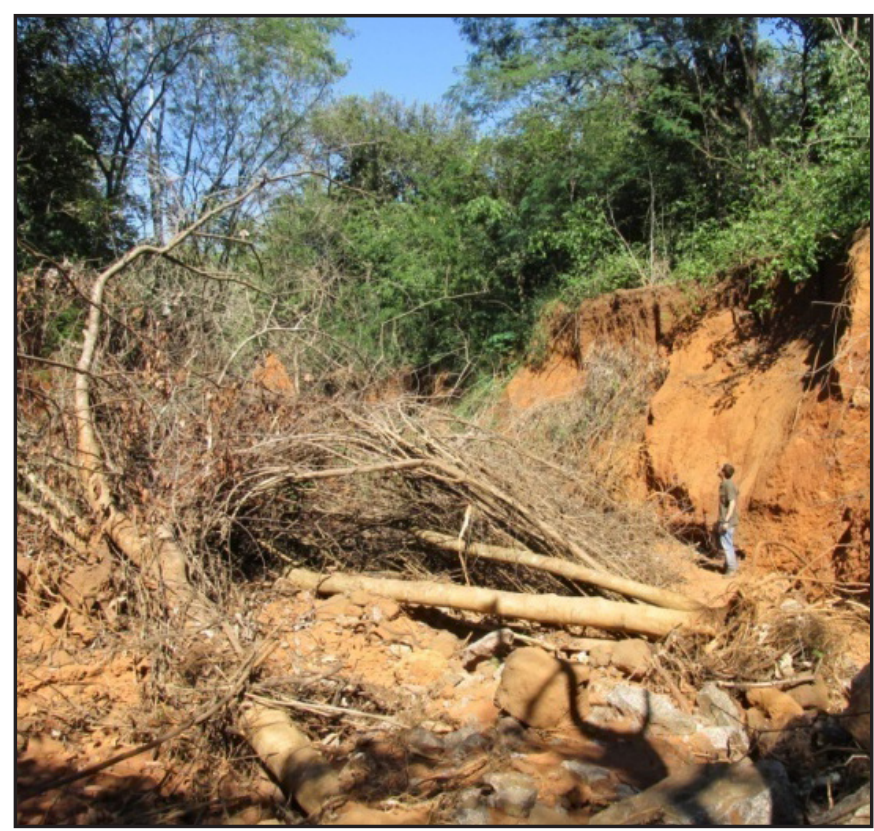

Source: FMA (2015)

were surveyed, together with the City Hall of Palmas.

The analysis started from the location of the gully, which is approximately 500 (five hundred) meters from the Metropolitan Guard of Palmas building, inside the Cesamar Park, from the end of the gully, that is, from the point downstream of the headwaters. Figure 1 shows the georeferenced location of the erosive process at the beginning of the surveys.

The technical surveys were carried out from the year 2015 to April 2016, and at each recorded point, using the GPS, at the margin of the gully, the width to the posterior margin was estimated.

With the data collected in loco and satellite images analyzed, and also through research and studies related to the subject, according to the specifications of the area, some measures of stabilization of the erosive process were proposed. Figures 02 and 03 present the surveys and measurements estimaded at the degradation site.

\section{Results and discussion}

Initially, it was identified that the predominant vegetation in the study area is the cerrado restricted sense, mixed with closed formations, as described by Teixeira (2015) with low trees and twisted trunks and with dominance of shrubs and sub-shrubs, surrounding the gully and other slopes.

In the first surveys, it was verified that the gully had a linear shape, as described by Augustin and Aranha (2006), presenting small branches and with a cross section being predominantly rectangular, in a " $\mathrm{U}$ " format, usually found in regions where soil and subsoil are easily erodible, as is the case of the sandy soil derived from the sandstones of the Pimenteiras Formation found in the area. The width varied from 4 (four) meters to 12 (twelve) meters approximately.

The erosion walls were almost vertical and had more
Figure 3 - Gully

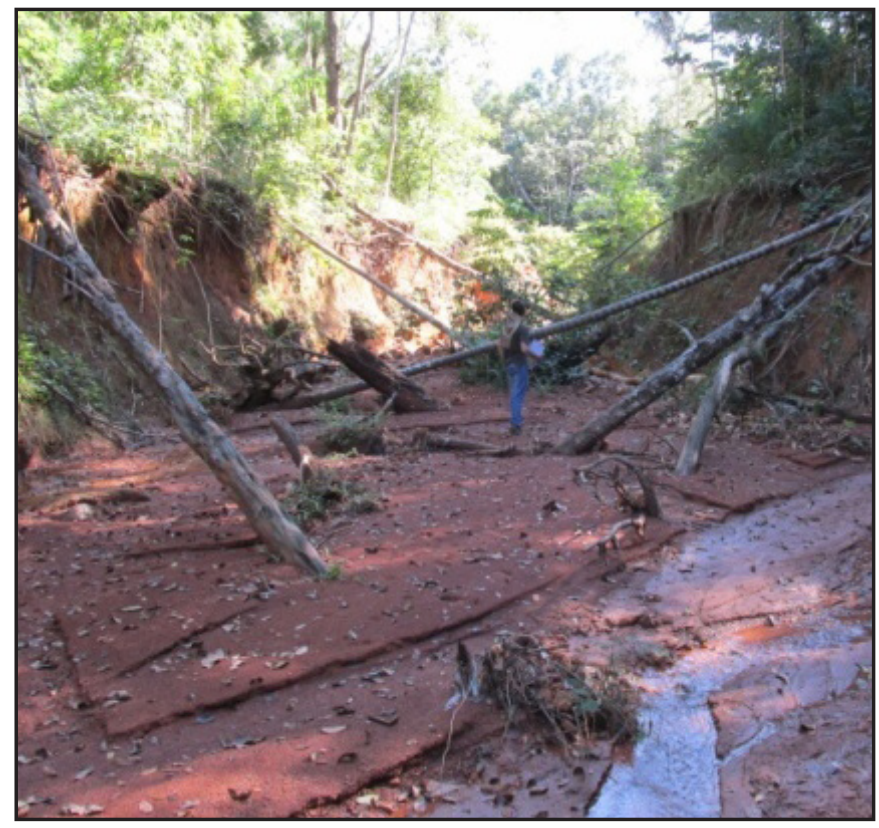

Source: FMA (2015)

significant heights, ranging from two (2) to five (5) meters. The length was approximately 250 (two hundred and fifty) meters.

It was observed that in some points slopes with negative inclination were found, due to the fact that the course of the drainage is eroding intensely the shallower parts of the canal wall. Marginal vegetation was compromised due to increased erosion, and the various pedestrian and cyclist trails within the Park that are closest to the gully were compromised, with the risk of serious accidents.

In order to evaluate the current situation of the erosion process, it was observed that this process evolved due to the discharge of the urban drainage network from the LO 07 and LO 05 avenues, which receives rainwater from the region northeast of the Park. due to the inefficiency of the energy dissipation mechanisms installed at the time of the drainage system, in addition to the great fragility of the soil inside the park.

It is worth mentioning that the erosion length increased considerably during the rainy season, advancing upstream near the point of launching the drainage (approximately 30 meters) and the LO 07 Avenue (approximately 80 meters). The exact location of the area can be seen in Figure 04.

Currently, erosion has a length of approximately 320 (three hundred and twenty) meters, an average width of 10 (ten) meters (reaching 16 meters in some points) and a maximum depth of 7 (seven) meters, in some points reaching the water level, thus characterizing the erosive process of the gully type.

There is another erosion with approximately 45 (forty-five) meters in length, which is adjacent to the erosion described above, and the "branching" of the two has coordinates 794208/8870845 (UTM Projection System, Datum Sirgas 2000, Zone 22S).

As the gully evolves, it is observed the suppression 
of the native vegetation, which was caused by the action of the rainwater, which when flowing with great energy through the interior of the gully, carries the soil of the bases of the slope, causing the undermining the ground, and consequently the fall of the vegetation.

Along the eroded section are found structures that were built in an attempt to contain the gullies, the gabions, but were insufficient, since most of these structures were undone by the overlapping of the terrain.

It is important to note that the channel of the erosive process is in continuous expansion, and is the result of the high energy in the flow of rainwater directed towards the natural drain through the point of launch of the urban drainage, and entails that: upstream eroded material is carried to downstream of it, resulting in a great contribution of sediments to the natural channel of the stream and to the lake of the Park Cesamar. Such sediments are coarser in the upper section of the course (upstream) and thinner in the lower section (near the lake).

The Municipality of Palmas carried out the excavation of ditches in order to contain the advance of the erosive process. Some ditches were filled by the eroded material upstream of them, showing to be insufficient to contain the advance of the erosive process.

The erosive processes initiated by rainfall due to surface and subsurface runoff forces have the ability to derive the start and drag of the soil particles (ZUQQUETTE et al, 2016).

Bertoni \& Lombardi Neto (2005) warn that the factors that contribute to the accentuation of the water erosion process are: slope, shape and length of the terrain as a topographic factor. That is, the greater the length of the slope, the greater the velocity of the water and thus the higher the kinetic energy to carry the sediments, increasing erosion and making it more intense.

With the results obtained in the surveys it was possible to propose measures for the immediate and attenuating intervention of the erosive process observed in slopes and bed of water course affluent to the Brejo Comprido Stream, caused by the discharges of urban drainage network from part of the LO 07 avenues and LO 05, in green area 304 (AVSE 33).

The proposals for mechanical and vegetative interventions must observe all the norms related to the slope control works foreseen in the legislation for damping the gully, in this article we list the following, since the drainage discharges have accentuated the problem, thus requiring measures of dissipation of water energy:

- Construction of levels downstream of the launch and upstream of the gully

These levels would act as power dissipactors, constructed to decrease the velocity and energy of the flow, originating from the conduit that drains pluvial water from the drainage system, as shown in Figure 05.

- Smoothness of slopes followed by planting of grasses

It is necessary to soften the slope angulation because they, in most parts, have negative angulation. The lower the angle of inclination of the slope, the greater the possibility of overlapping of them, further aggravating the situation. Slopes of $45^{\circ}$ to $60^{\circ}$ are suggested. At every 3 (three) meters of height of the embankment, it is proposed to make a level. After decreasing slope

Figure 4 - Localization the erosiv process from the court AVSE 33

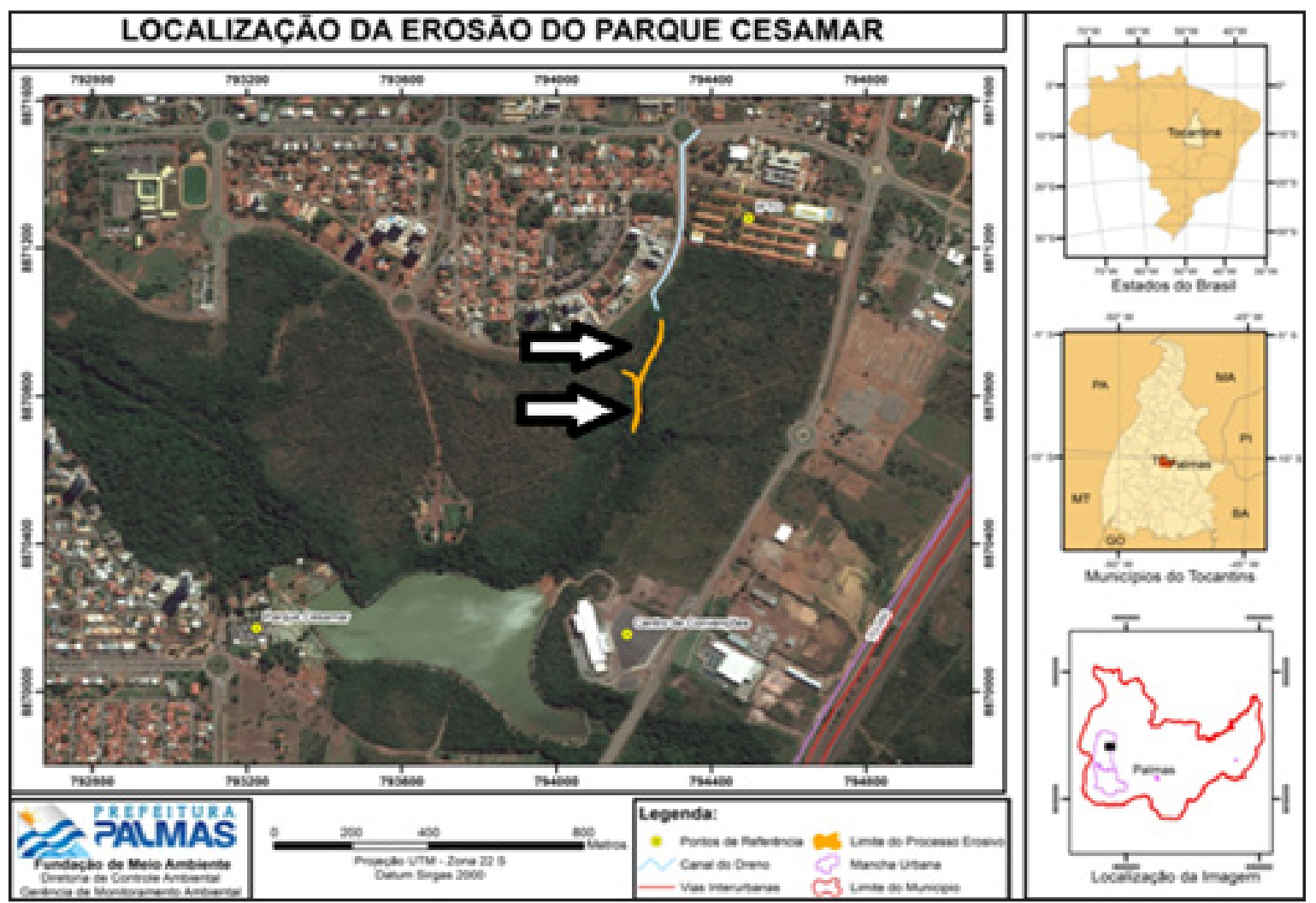

Source: FMA (2016) 
Figure 5 - Representation sketch of levels

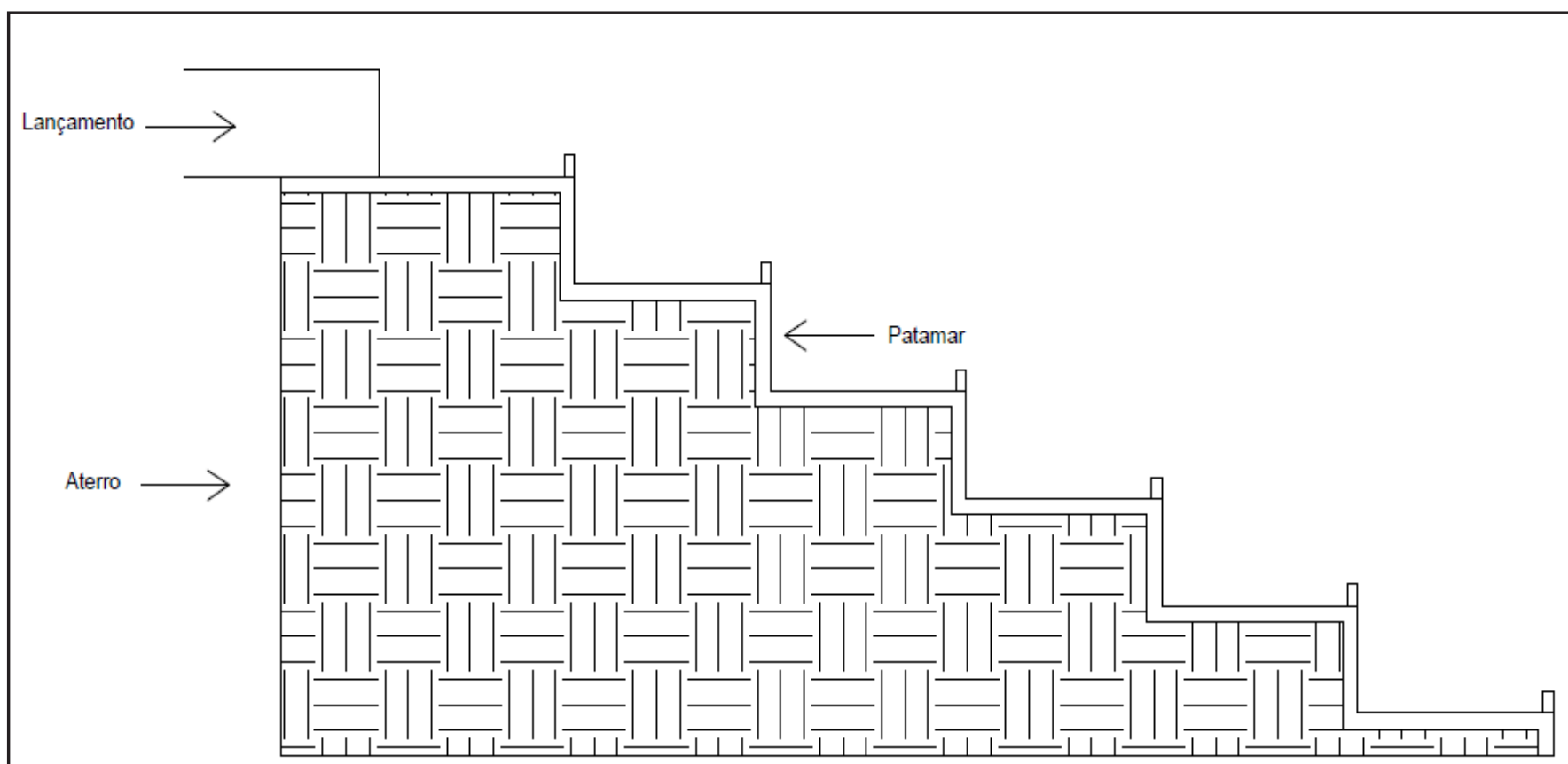

Source: Own authorship

slope, grasses will be planted, which act as energy sinks and help reduce runoff, contributing to the erosion process delay.

- Protection of slopes and gully bottoms

Used rubber tires, fixed with crumpled stones and wire, forming a structure that forms a kind of "mesh" that works as a power dissipactors. This structure aims to protect the slopes and bottom of the gully from higher erosion states.

\section{Conclusions}

From the analysis of the process and the Environmental Monitoring on the presented problem, it is concluded that this is a serious environmental problem. As time goes by, the gullies tend to increase in size and all this solid material is destined for the Brejo Comprido stream as well as the lake of the Cesamar Park. If no intervention is performed, the severity of the problem tends to become more acute, leading to complete silting of such bodies of water.

Recovery proposals have the status of execution in urgency, given the severity of the problem. Still in this sense, it is known that these interventions, however good they may be, do not solve the problem definitively. A more elaborate work plan, involving the derivation of the network in its entirety, is necessary, since the flow launched upstream of the gully is very high, this linked to a vulnerable soil, results in erosive processes that evolve over time.

It is also recommended to extend greater care and precaution in order to maintain adequate environmental conditions for the maintenance of the sources existing in the gullies. In this sense, it is recommended to ob- serve all the norms referring to the works of erosive process control and related norms for improvements in the proposal.

\section{Thanks}

I thank the team of the Municipal Environment Foundation that entrusted me with access to the data obtained throughout the process, for teaching me every day with the professionalism and dedication of each one to offer the best work and the best results.

To the Federal University of Tocantins for giving me access to quality teaching and stimulating scientific research.

\section{References}

AUGUSTIN, C. H. R. R.; ARANHA, P. R. A. A ocorrência de voçorocas em Gouveia, MG: características e processos associados. GEONOMOS, v. 14, n. 1,2, p. 75-86, 2006.

BERTONI, J. \& LOMBARDI NETO, F. Conservação do solo. 5. ed. Ícone: São Paulo, 2005. 355p.

CARVALHO, Daniela Paiva et al. Ocorrência de voçorocas (gullies) na rodovia BR 174, trecho Manaus-Presidente Figueiredo (Am): gênese, morfologia e previsão de riscos. 2017.

DA SILVA SANTANA, Ana Luiza; ARAUJO, Glaucio Luciano. Erosão do solo em uma propriedade rural no município de Abre Campo (MG). Anais do Seminário Científico da FACIG, n. 3, 2018. 
FOOD AND AGRICULTURE ORGANIZATION OF THE UNITED NATIONS (FAO). Status of the World's Soil Resources. Roma: Food and Agriculture Organization of the United Nations, 2015.

MOREIRA, Rafael Ferro; POLIVANOV, Helena. Potencial erosivo de perfil de solo de Talude de corte através de ensaios de Inderbitzen. Geo UERJ, n. 32, p. 32158, 2018.

NORONHA, Erika da Silva. Controles para distribuição de voçorocas na área do Centro de Instruções de FormosaCIF. 2015.

PASCOTO, Tamara Vieira; FUREGATTI, Simone Andrea; PEIXOTO, Anna Silvia Palcheco. Classificação das Erosões da Área Urbana de São Manuel-SP. 2018.

TEIXEIRA, Ana Magalhães Cordeiro. Florística e estrutura da vegetação em Cerrado sentido restrito no Parque Estadual de Terra Ronca, Goiás: método RAPELD. 2015.

ZANATTA, Felipe Augusto Scudeller et al. Antropogeomorfologia e Problemática Erosiva em Área Rural Degradada, Marabá Paulista (SP). Revista do Departamento de Geografia, n. spe, p. 199-207, 2017.

ZUQUETTE, Lazaro Valentin; CARVALHO, José Alcino Rodrigues; DE BARROS YAMANOUTH, Gisele Ribeiro. Feições erosivas na bacia do córrego do Espraiado, São Pedro (SP), seus tipos e evolução entre 1972-2002. Revista Brasileira de Geociências, v. 37, n. 2, p. 414-425, 2016. 